\title{
Effects of Colored Light on Growth and Nutritional Composition of Tilapia, and Biofloc as a Food Source
}

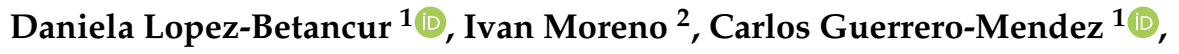 \\ Domingo Gómez-Meléndez ${ }^{1}$, Manuel de J. Macias P. ${ }^{3}$ and Carlos Olvera-Olvera ${ }^{1, *(1)}$ \\ 1 Unidad Académica de Ingeniería Eléctrica, Universidad Autónoma de Zacatecas, Campus Siglo XXI, \\ Zacatecas C.P. 98160, Mexico; danielalopez106@uaz.edu.mx (D.L.-B.); \\ guerrero_mendez@uaz.edu.mx (C.G.-M.); domag5@hotmail.com (D.G.-M.) \\ 2 Unidad Académica de Ciencia y Tecnología de la Luz y la Materia, Universidad Autónoma de Zacatecas, \\ Campus Siglo XXI, Zacatecas C.P. 98160, Mexico; imorenoh@uaz.edu.mx \\ 3 Unidad Académica de Ciencias Química, Universidad Autónoma de Zacatecas, Campus Siglo XXI, \\ Zacatecas C.P. 98160, Mexico; mmacias@uaz.edu.mx \\ * Correspondence: colvera@uaz.edu.mx; Tel.: +52-492-107-0307
}

Received: 28 November 2019; Accepted: 30 December 2019; Published: 3 January 2020

\begin{abstract}
Light stimulation and biofloc technology can be combined to improve the efficiency and sustainability of tilapia production. A 73-day pilot experiment was conducted to investigate the effect of colored light on growth rates and nutritional composition of the Nile tilapia fingerlings (Oreochromis niloticus) in biofloc systems. The effect of colored light on the nutritional composition of bioflocs as a food source for fish was measured. Three groups were illuminated in addition to natural sunlight with colored light using RGB light emitting diodes (LEDs) with peak wavelengths $(\lambda)$ of $627.27 \mathrm{~nm}$ for red (R), $513.33 \mathrm{~nm}$ for green $(\mathrm{G})$, and $451.67 \mathrm{~nm}$ for blue (B) light. LED light intensity was constant $\left(0.832 \mathrm{~mW} / \mathrm{cm}^{2}\right)$, and had an 18-h photoperiod of light per day throughout the study. The control group was illuminated only with natural sunlight (natural). Tilapia had an average initial weight of $0.242 \mathrm{~g}$. There was a significant effect of colored light on tilapia growth and composition. The R group showed the best growth rate, highest survival, and highest lipid content. The B group showed homogeneous growth with the lowest growth rate and lipid content, but the highest protein level. On the other hand, the biofloc composition was influenced by the green light in the highest content of lipids, protein, and nitrogen-free extract.
\end{abstract}

Keywords: food science; light; color; LEDs; sustainable aquaculture; fish production; preliminary results

\section{Introduction}

Aquaculture is one of the fastest-growing food production areas and it is one of the most important sources of food, nutrition, income, and livelihood for hundreds of millions of people worldwide [1]. By 2030, the production of freshwater species such as carp, catfish, and tilapia is expected to represent about $60 \%$ of total aquaculture production [2,3]. However, fish farming requires the use of land, freshwater, and environmental resources, which are increasingly scarce and expensive worldwide. By 2030, the world could have a global water deficit of $40 \%$ in the usual commercial scenario, and by 2050, the demand for water is expected to increase by $55 \%$ in all sectors of production [4]. Therefore, an increase in aquaculture production must be carefully planned, minimizing the environmental impact and optimizing the use of natural resources.

Today, sustainable aquaculture systems produce more fish without affecting the environment, such as using biofloc technology (BFT). In systems with BFT, there are limited exchanges of water 
and, thus, there is an accumulation of organic matter and nutrients that promote the development of a microbial community called a bioflocs [5]. Bioflocs are conglomerates of phytoplankton, bacteria, zooplankton, microbial grazers, and particulate organic matter, which are mainly heterotrophic bacteria. When this conglomerate is mixed with an added external carbon source, the growth of heterotrophic bacteria is stimulated and the absorption of nitrogen occurs through the production of microbial proteins, which serve as a food source for fish that is available $24 \mathrm{~h}$ per day [6-9]. Biofloc systems are mainly used to cultivate tilapia (Oreochromis sp.) and white shrimp (Litopenaeus vannamei) because both species can eat biofloc and live in environments with high levels of turbidity [10]. The biofloc community can also be used to improve water quality by adding carbon sources to the pond [11,12].

The development of new technologies and scientific studies in aquaculture is essential to improve intensive fish production. A promising improvement in aquaculture comes from light emitting diode (LED) lighting. It has been shown that lighting in aquaculture can influence embryonic development, releasing reproductive hormones that increase fish growth $[13,14]$. However, fish are visual feeders that need a minimum light intensity to eat and, thus, grow and develop [15]. In addition to the influence on embryonic development, the intensity and spectrum light in certain photoperiods (intensity, duration, and periodicity) can be used to alter and control the growth of fish [16-20]. Photoperiods also influence the release of reproductive hormones, which play an important role in fish reproduction and growth [13]. In addition, under short wavelengths such as blue light, melatonin (which is the hormone that is responsible for sleep) decreases in the bass fish, and the lower the melatonin, the longer the fish are awake, and the more they feed [21]. However, banana shrimp (Penaeus merguiensis) have a faster growth related to the intensity of the lighting, and the higher the light intensity, the less the shrimp feed, but they grow faster, possibly because of better efficiency of food assimilation [22]. For shrimp with BFT, it was observed that when low light intensity was used, shrimp production decreased by $48 \%$, and the density of microalgae, zooplankton, and rotifers also decreased by $60 \%, 60 \%$, and $90 \%$, respectively [23].

Tilapias are generally diurnal feeders that feed at different time periods during the day [24]. Using fluorescent tube lamps with a photoperiod of 18L:6D and illuminance of 2500 lux, it is possible to produce more Nile tilapia seeds (percentage of spawning synchrony and percentage of the sac and swim-up fry stages) compared to a shorter photoperiod with less illumination (2500 lux/15 h, 2500 lux/12 h, 500 lux/18 h, 500 lux/15 h, and 500 lux/12 h) [14]. The promising new LED light technology, which has not been widely explored in aquaculture, especially in BFT systems, can be a useful light source tool if the light parameters (intensity, color, and periodicity) are analyzed and applied to obtain benefits in the production of Nile tilapia in BTF. The rapid development of LED technology in recent years has exceeded the characteristics of incandescent lamps in luminous efficiency, low heat emission, robustness, environment resistance, non-toxicity, durability, and adjustable light intensity and wavelength, which allows precise control of the light spectrum $[25,26]$. The aim of this study was to investigate the effect of using colored LED light on tilapia growth, the nutritional composition of the Nile tilapia fingerlings, and the composition of the bioflocs that are used as a food source for fish.

\section{Materials and Methods}

\subsection{Ethics Statement}

All work with animals in this research was done in accordance with the "Guidelines for the Use of Fishes in Research" published by the American Society of Ichthyologists and Herpetologists (https://www.asih.org/sites/default/files/2018-05/asf-guidelines-use-of-fishes-inresearch-2013.pdf) and complied with the Mexican law on experimental animals according to the protocols: NOM-062-ZOO-1999 and NOM-033-SAG/ZOO-2014.

The experimental design and the fish-use protocol were approved within the project "LED lighting to improve the production of tilapia in biofloc systems" by the ethics committee for animal research at the "Autonomous University of Zacatecas" (authorization number: ACS/UAZ/036/2018). 
The light intensities used in all the experiments did not exceed values that were observed in natural waters. This study did not include endangered or protected species. All fish were acclimatized for greenhouse conditions for 2 weeks, with the lamps off (the fish only received natural light), before the start of the experiment. The duration of our experiment was 73 days and 489 Nile tilapia fingerlings (Oreochromis niloticus) were used. During the planning stage of the experiment, water quality parameters (temperature, dissolved oxygen, and $\mathrm{pH}$ ) were monitored twice a day to confirm optimal living conditions for tilapia. The average water quality parameters for fishponds were: $28.50^{\circ} \mathrm{C}$ for temperature, $6.68 \mathrm{mg} / \mathrm{L}$ for dissolved oxygen, 7.9 for $\mathrm{pH}, 0.08 \mathrm{mg} / \mathrm{L}$ for ammonia, and $0.83 \mathrm{mg} / \mathrm{L}$ for total ammonia nitrogen. The average ammonia and total ammonia nitrogen values were monitored every 8 days. The fishponds were supplied with a $300 \mathrm{~W}$ thermostat heater (Grupo acuario LOMAS, Ciudad de Mexico, CDMX, Mexico) to avoid temperature variations. Aeration was provided by a Sino-Aqua blower (1/2 Hp of power, and 9" membrane diffuser discs). Additionally, $10 \%$ of the tank water was exchanged each week. During the progress of this experiment, 105 fish died from natural causes such as acclimatization, and no specific pathologies were observed to determine if the fish should be euthanized. At the end of the experiment 384 fish were sacrificed. We carefully used standardized procedures for fish euthanasia. Since Nile tilapia do not tolerate cold water, they were sacrificed by rapid chilling (hypothermic shock) by keeping the tilapia in ice water at $2{ }^{\circ} \mathrm{C}$ for $10 \mathrm{~min}$ after the opercular movement stopped. The fish were stored in a freezer until chemical analysis of their nutritional composition (approximately $72 \mathrm{~h}$ ).

\subsection{Laboratory Facilities and Fish Stocking}

A 73-day experiment was performed in a greenhouse in the prototypes laboratory at the Autonomous University of Zacatecas, Mexico. Before the experiment started, 489 Nile tilapia (O. niloticus) fingerlings were purchased from a commercial hatchery (AQUAMOL S.C. DE R.L., Jamay, Jal., Mexico), and moved to the greenhouse, where they underwent a period of acclimatization. The Nile tilapia fingerlings had an initial average weight of $0.242 \pm 0.01 \mathrm{~g}$. They were randomly distributed, with a same density of $0.2 \mathrm{~kg} / \mathrm{m}^{3}$ (approximately 123 fish per tank, and exactly $30 \mathrm{~g}$ of biomass per tank), in circular tanks (150-L capacity, $39 \mathrm{~cm}$ high $\times 70 \mathrm{~cm}$ in diameter) under natural light. This is a pilot study because in this experimentation there were no replicated tanks $(n=1)$. All results presented are preliminary results, but significant because each tank contained a large number of fish.

\subsection{Experimental Design and Setup}

The experiment was designed to study the effect of colored light under real light conditions. The experiment could also be transferred to real production because real conditions were present in the experiments, such as all four treatments received natural light, which is consistent with aquaculture farms.

This investigation implemented a special change, in addition to receiving natural light, three treatments were illuminated with red, green, and blue LED lamps for $18 \mathrm{~h}$ per day. The illumination was provided by RGB (red, green, and blue monochromatic light) LED lamps with peak wavelengths ( $\lambda$ ) of $\lambda=627.27 \mathrm{~nm}$ for the red light treatment (R), $\lambda=513.33 \mathrm{~nm}$ for the green light treatment (G), and $\lambda=451.67 \mathrm{~nm}$ for the blue light treatment (B). LED lamps were positioned $25 \mathrm{~cm}$ above the water surface, with the purpose that the lamp opening angle $\left(110^{\circ}\right)$ should focus completely on the water surface of the entire tank diameter. LED light intensity of all the lamps was constant at $0.832 \mathrm{~mW} / \mathrm{cm}^{2}$, and the natural light provided by the sunlight inside the greenhouse had a maximum of irradiance of $0.95 \mathrm{~mW} / \mathrm{cm}^{2}$ at 14:00 h. The fourth treatment, which we called "Natural" light treatment, only received natural light, and served as a control treatment. The lighting conditions for the four treatments are shown in Figure 1. 


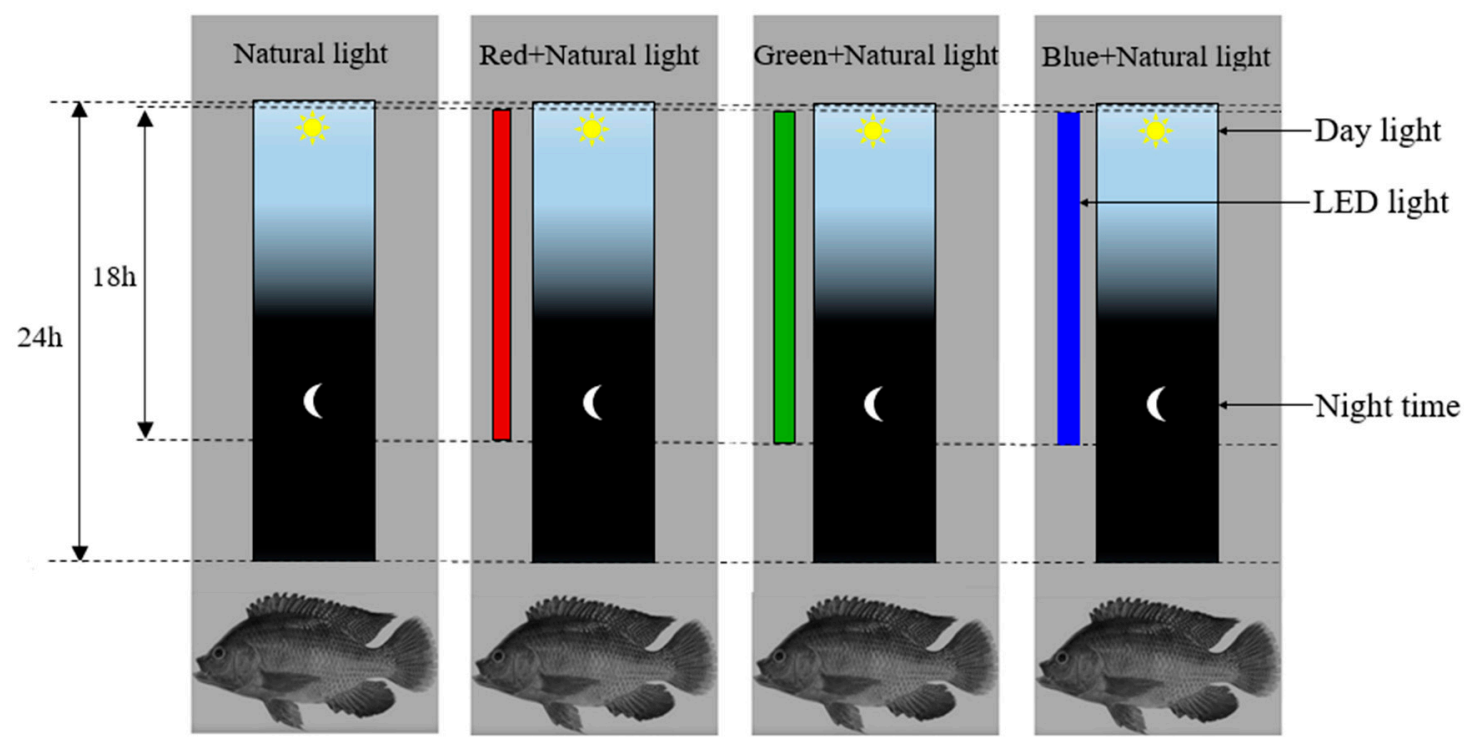

Figure 1. Light periods received by each tank during this research. All treatments received natural light, but three of the treatments were also illuminated with red, green, and blue colored light, which was provided by an LED lamp, with a photoperiod of $18 \mathrm{~h}$ per day.

\subsection{Characterization of LED Lamps}

The LED lamps used in this experiment were optically characterized using a spectrophotometer (USB2000, Ocean Optics, Largo, FL, USA) and a NIST calibrated radiometer (ILT-1400, International Light Technologies Inc., Peabody, MA, USA). Wavelength $(\lambda)$ and spectral width $(\Delta \lambda)$ parameters were measured using the spectrophotometer device. The irradiance or radiant power density on the water surface of each tank was measured using the radiometer. The measured LED lamp parameters are presented in Table 1, where the average irradiance was $0.832 \mathrm{~mW} / \mathrm{cm}^{2}$. Figure 2 also shows the spectral power distribution of light emitted by each colored LED lamp.

Table 1. Optical properties of light colors in light emitting diode (LED) lamps: red (R), green (G), and blue (B).

\begin{tabular}{cccc}
\hline \multirow{2}{*}{ Parameters } & \multicolumn{3}{c}{ LED Lamps } \\
\cline { 2 - 4 } & $\mathbf{R}$ & $\mathbf{G}$ & $\mathbf{B}$ \\
\hline$\lambda(\mathrm{nm})$ & 627.27 & 513.33 & 451.67 \\
$\Delta \lambda(\mathrm{nm})$ & 16.92 & 32.80 & 23.75 \\
Irradiance $\left(\mathrm{mW} / \mathrm{cm}^{2}\right)$ & 0.87 & 0.83 & 0.80 \\
\hline
\end{tabular}

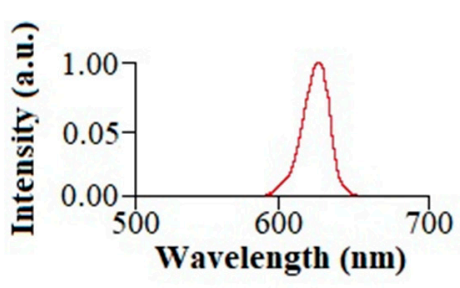

a.

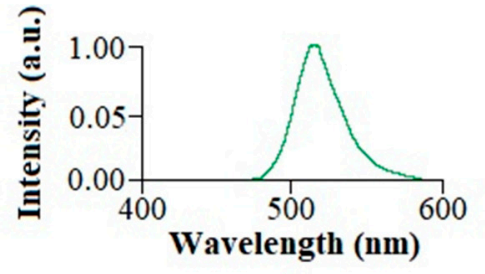

b.

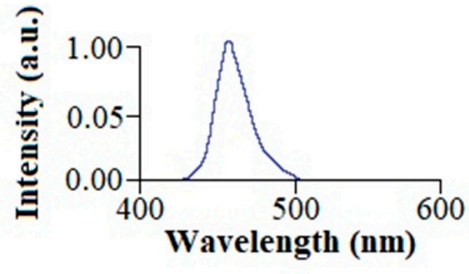

c.

Figure 2. The spectral power distribution of the RGB LED lamps used in the study: (a) R LED lamp; (b) G LED lamp; and (c) B LED lamp. 


\subsection{Nile Tilapia Fingerlings and the Biofloc System}

All treatment groups began the study with tap water, which was previously aerated for 1 week to allow water dechlorination. No water exchange was made, and the formation of the biofloc started from zero when the tilapia arrived. Each tank was fixed at $29^{\circ} \mathrm{C}$ using a $300 \mathrm{~W}$ thermostat heater to avoid high temperature variations, and to provide a comfortable temperature for the fish. Pure cane sugar was added to each tank as a carbon source, which was calculated using the method described by De Schryver et al. [27]. The use of a carbon-to-nitrogen $(\mathrm{C} / \mathrm{N})$ ratio of 20:1 in the tanks ensures the water quality during the biofloc formation because we guarantee a low level of total ammonia nitrogen (TAN) in the water $[28,29]$. The fish were fed by hand twice a day using the commercial diet I during the first month, and then using the commercial diet II, according to the requirements of the growth stage. The nutritional composition of the commercial diet I, commercial diet II, and cane sugar used are listed in Table 2. The daily amount of food was adjusted every week (the feeding rate started with $10 \%$ of the fish's weight per day and it decreased to $5 \%$ per day) according to the growth of the fish, fish survival, and the biofloc that was expected in each tank. The fish feed composition was provided by the manufacturer and was also corroborated based on a bromatology test to guarantee the consumption and quality of the feed. During the experimental period, the tanks were checked by hand every day, and any dead fish were removed and recorded.

Table 2. Feed composition for tilapia and cane sugar used as a carbon source.

\begin{tabular}{|c|c|c|c|c|c|c|}
\hline & \multicolumn{6}{|c|}{ Feed } \\
\hline & $\begin{array}{c}\text { Commercial } \\
\text { Diet I } \\
\text { (Manufacturer) }\end{array}$ & $\begin{array}{c}\text { Commercial } \\
\text { Diet I } \\
\text { (Laboratory) }\end{array}$ & $\begin{array}{c}\text { Commercial } \\
\text { Diet II } \\
\text { (Manufacturer) }\end{array}$ & $\begin{array}{c}\text { Commercial } \\
\text { Diet II } \\
\text { (Laboratory) }\end{array}$ & $\begin{array}{l}\text { Cane Sugar } \\
\text { (Manufacturer) }\end{array}$ & $\begin{array}{l}\text { Cane Sugar } \\
\text { (Laboratory) }\end{array}$ \\
\hline Moisture (\%) & 12.00 & 7.90 & 12.00 & 8.10 & 0.00 & 1.80 \\
\hline Crude protein $(\%)$ & 53.00 & 43.00 & 32.00 & 40.90 & 0.00 & 0.30 \\
\hline Lipids (\%) & 15.00 & 12.30 & 6.00 & 12.80 & 0.00 & 0.00 \\
\hline Crude fiber (\%) & 2.50 & 1.70 & 6.00 & 2.20 & 0.00 & 3.30 \\
\hline Ash (\%) & 12.00 & 7.80 & 15.00 & 10.00 & 0.00 & 0.10 \\
\hline Nitrogen-free extract (\%) & 5.50 & 27.30 & 29.00 & 26.00 & 100.00 & 94.50 \\
\hline
\end{tabular}

\subsection{Water Quality Parameters}

Temperature, dissolved oxygen (measured by the YSI model 550A dissolved oxygen meter device (Yellow Springs Instrument Co., Yellow Springs, OH, USA)), and pH (measured by the Hanna model HI 98127 device (Hanna Instruments, Woonsocket, RI, USA)) were measured twice a day in each tank at 10:00 and 20:00 h. Ammonia-nitrogen $\left(\mathrm{NH}_{3}-\mathrm{N}\right)$, which is one form of ammonia in TAN that is toxic for fish, was regulated by adding cane sugar. $\mathrm{NH}_{3}-\mathrm{N}$ levels were measured once per week in the tanks using the ammonia checker device (Hanna model HI715 (Hanna Instruments, Woonsocket, RI, USA)). In addition, the TAN value was calculated using a modified mathematical expression described by Boyd and Tucker [30], which is written as follows:

$$
\mathrm{TAN}=\left(\mathrm{NH}_{3}-\mathrm{N}\right) \times\{1+\operatorname{antilog}[0.09018+(2729.92 /(273.15+\mathrm{T}))]-p H\},
$$

where TAN is the total ammonia nitrogen, $\left(\mathrm{NH}_{3}-\mathrm{N}\right)$ is the ammonia-nitrogen, $\mathrm{T}$ is the water temperature $\left({ }^{\circ} \mathrm{C}\right)$, and $\mathrm{pH}$ is the water $\mathrm{pH}$.

\subsection{Growth Rates}

Throughout the experiment, biometric measurements were made every week in a group of randomly selected of 15 fish in each tank. At the end of the experiment, all the fish were weighed and measured, and the growth rates were reported as the mean \pm standard deviation. According to the final number of fish in each treatment, there were 127 fish that underwent $R$ treatment, 79 fish that underwent $G$ treatment, 94 fish that underwent B treatment, and 84 fish that underwent the Natural treatment. The mean \pm standard deviation is presented for the fish weight and length. Additional 
measurements to evaluate fish growth were used, as follows: initial weight (g/fish), final weight (g/fish), final body length (cm/fish), survival (\%), specific growth rate (SGR), daily weight gain (DWG), and feed conversion rate (FCR). The mathematical expressions of the evaluation metrics were extracted from published studies [31,32]. These evaluation metrics are written as follows:

$$
\begin{aligned}
& \text { Initial weight }(\mathrm{g})=(\text { initial biomass }(\mathrm{g})) /(\text { initial number of fish }), \\
& \text { Final weight }(\mathrm{g})=(\text { final biomass }(\mathrm{g})) /(\text { final number of fish }), \\
& \text { Final body length }(\mathrm{cm})=\frac{\sum_{\mathrm{i}=0}^{\text {Final number of fish }} \text { fish body length }(\mathrm{i})}{\text { final number of fish }}, \\
& \text { Survival }(\%)=(\text { final number of fish }) /(\text { initial number of fish }) \times 100 \%, \\
& \text { SGR }(\% / \text { day })=\frac{\ln (\text { final weight }(\mathrm{g}))-\ln (\text { initial weight }(\mathrm{g}))}{\text { number of days }} \times 100 \%, \\
& \text { DWG }(\mathrm{g} / \text { day })=(\text { final weight }(\mathrm{g})-\text { initial weight }(\mathrm{g})) /(\text { number of days }), \\
& \text { FCR }=(\text { total feed intake }(\mathrm{g})) /(\text { total wet weight gain }(\mathrm{g})),
\end{aligned}
$$

where the initial biomass is the weight of all the fish in each tank at the beginning of the experiment, and the final biomass is the weight of all the fish at the end of the experiment. The total feed intake is the amount of food supplied to the fish, and the total wet weight gain is the difference between the final weight and the initial weight of the entire biomass.

\subsection{Nutritional Composition of the Fish Body and Bioflocs}

Composition of the fish body is valuable information about the nutritional contribution that the fish meat will have for a consumer. A biofloc nutritional composition study also provided information on whether the diet of the fish could be completed correctly using the biofloc. At the end of the experiment, all the fish were caught for a biomass analysis. The water in the tanks was sieved using a 200-mesh screen to maintain the greatest amount of biofloc. The composition of the fish body and the bioflocs were determined by the composition of lipids, moisture, crude protein, crude fiber, ash, and nitrogen-free extract, according to standard methods $[33,34]$. The values were determined using Soxhlet extraction apparatus while the other parameters were determined with bromatology using gravimetric techniques. The nutritional composition analysis was performed by the Chemical Laboratory of Special Studies at the Autonomous University of Zacatecas.

\subsection{Statistical Analysis}

All the measured data and the metrics that were calculated in this research were analyzed to achieve a performance evaluation and a broad comparison between the four light treatments. Since the parameters obtained from the tanks are mean values, a one-way analysis of variance (ANOVA), which compares the "variation" of a group of mean values, was used.

Water quality parameters cannot be analyzed using ANOVA because there are no replicate tanks $(n=1)$. However, growth rates can be analyzed because each tank had many final fish as follows: $n=127$ for R treatment, $n=79$ for G treatment, $n=94$ for B treatment, and $n=84$ for Natural treatment. Thus, the growth rates were analyzed using the one-way ANOVA, followed by Tukey's test, with a significance level of $5 \%$. Before performing the one-way ANOVA evaluation, the hypothesis of equality (homogeneity) of variances was verified using the Levene's test. Data analysis of the biofloc and fish nutritional composition was performed using the mean values of three sample replicates. 


\section{Results}

\subsection{Water Quality Parameters}

The average values of the water parameters remained approximately equal between all groups during the experimental period. Thus, a constant temperature was maintained, with a variation of less than $1{ }^{\circ} \mathrm{C}$, the $\mathrm{pH}$ value showed a difference below $1.25 \%$, the variation of ammonia-nitrogen $\left(\mathrm{NH}_{3}-\mathrm{N}\right)$ was less than $0.03 \mathrm{mg} / \mathrm{L}$, and the difference in dissolved oxygen and TAN were less than 0.07 and $0.17 \mathrm{mg} / \mathrm{L}$, respectively. The mean values of water quality parameters were calculated, and they are shown in Table 3.

Table 3. Water quality parameters.

\begin{tabular}{ccccc}
\hline \multirow{2}{*}{ Parameters } & \multicolumn{4}{c}{ Treatments } \\
\cline { 2 - 5 } & $\mathbf{R}$ & $\mathbf{G}$ & $\mathbf{B}$ & Natural \\
\hline Temperature $\left({ }^{\circ} \mathrm{C}\right)$ & $28.03 \pm 1.03$ & $28.38 \pm 0.96$ & $28.94 \pm 1.22$ & $28.65 \pm 0.93$ \\
Dissolved Oxygen $(\mathrm{mg} / \mathrm{L})$ & $6.65 \pm 0.58$ & $6.67 \pm 0.43$ & $6.71 \pm 0.47$ & $6.72 \pm 0.47$ \\
pH & $7.91 \pm 0.17$ & $7.91 \pm 0.16$ & $7.92 \pm 0.16$ & $8.01 \pm 0.20$ \\
$\mathrm{NH}_{3}-\mathrm{N}(\mathrm{mg} / \mathrm{L})$ & $0.07 \pm 0.01$ & $0.07 \pm 0.01$ & $0.08 \pm 0.01$ & $0.10 \pm 0.01$ \\
TAN $(\mathrm{mg} / \mathrm{L})$ & $0.79 \pm 0.18$ & $0.76 \pm 0.21$ & $0.86 \pm 0.14$ & $0.93 \pm 0.22$ \\
\hline
\end{tabular}

Data are presented as the mean \pm standard deviation.

\subsection{Growth Rates}

Mean weight, mean body length, survival, specific growth rate, and feed conversion ratio were used as metrics to evaluate the effect of colored light. According to the measured data, the $\mathrm{R}$ group showed the highest final weight among the fish, and it also had the lowest initial weight. Therefore, the R group had the highest performance, with the best growth rates and DWG (see Table 4). In addition, the data obtained show that the $R$ and $G$ groups presented the best gains in weight and length. However, the $\mathrm{G}$ group had the worst survival. The feed conversion ratio was better in the $\mathrm{R}$ and Natural groups compared with the other groups. The SGR value was significantly higher in the groups $\mathrm{R}$ and $\mathrm{G}$ compared with the other groups. The quantitative distribution of the final weight of the fish for each group is shown in Figure 3.

Table 4. Growth rates of Nile tilapia.

\begin{tabular}{ccccc}
\hline Parameters & \multicolumn{4}{c}{ Treatments } \\
\cline { 2 - 4 } & $\mathbf{R}$ & $\mathbf{G}$ & $\mathbf{B}$ & Natural \\
\cline { 2 - 5 } & 30 & 30 & 30 & 30 \\
Initial biomass (g) & 0.2 & 0.2 & 0.3 & 0.3 \\
Initial weight (g/fish) & 133 & 132 & 111 & 113 \\
Initial number of fish & 2193 & 1330 & 1461 & 1362 \\
Final Biomass (g) & 2163 & 1300 & 1431 & 1332 \\
Total biomass gained (g) & 127 & 79 & 94 & 84 \\
Final number of fish & $17.3 \pm 3.3^{\mathrm{a}}$ & $16.8 \pm 3.1^{\mathrm{a}}$ & $15.5 \pm 2.8^{\mathrm{b}}$ & $16.2 \pm 3.0^{\mathrm{ab}}$ \\
Final individual weight (g/fish) & $8.2 \pm 1.0^{\mathrm{a}}$ & $8.0 \pm 0.9^{\mathrm{a}}$ & $7.7 \pm 0.9^{\mathrm{b}}$ & $7.9 \pm 0.8^{\mathrm{ab}}$ \\
Final individual body length (cm/fish) & 95.5 & 59.9 & 84.7 & 74.3 \\
Survival (\%) & 6.0 & 5.9 & 5.6 & 5.7 \\
SGR (\%/day) & 0.2 & 0.2 & 0.2 & 0.2 \\
DWG (g/day) & 0.8 & 1.3 & 1.2 & 1.0 \\
FCR &
\end{tabular}

SGR = specific growth rate; DWR = daily weight gain; FCR = feed conversion rate. Data are presented as the mean \pm standard deviation. Values in the same row with different superscript letters indicate significant differences based on the one-way ANOVA and Tukey's test $(p<0.05)$. 


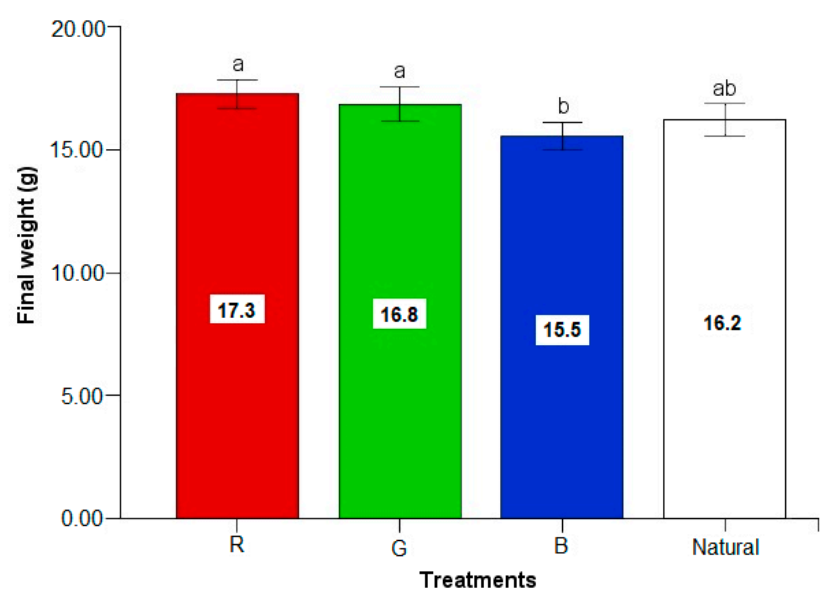

Figure 3. The mean final weight of the fish in each treatment. Each bar represents the mean with the standard deviation. Different letters (such as a, b, and ab) represent significant differences $(p<0.05)$.

\subsection{Nutritional Composition of the Fish Body and Bioflocs}

The mean values for nutritional composition of the fish and the nutritional composition of the bioflocs as a food source for fish are presented in Figures 4 and 5, respectively. The moisture value was higher in the body of the fish of group B. In addition, the body of the fish in groups B and Natural presented a higher concentration of crude protein compared to the other treatments. The mineral content (ash) in the fish in groups R, G, and Natural was less than that measured in the fish in group B. Lipids in the body composition of the fish were most influenced by the use of colored lights. Fish in group R showed a higher lipid content and nitrogen-free extract.
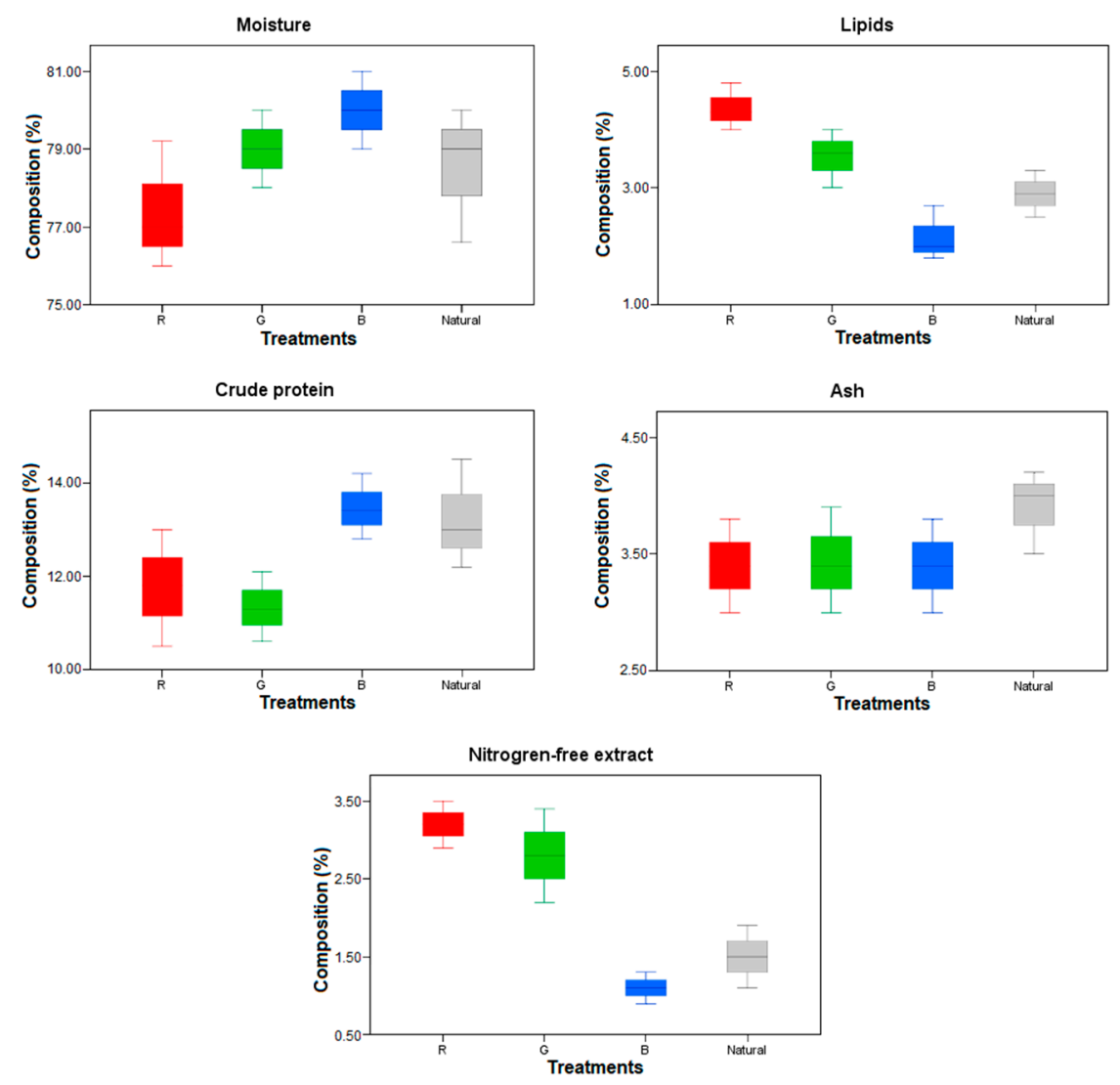

Figure 4. Box-and-whisker plots showing the nutritional composition of the fish (\%). 
Measurements of the mean nutritional composition of the bioflocs in the $G$ and Natural groups showed a higher concentration of crude protein compared to the other treatments. The ash composition in the bioflocs from the R and $G$ groups was lower than the content measured in the bioflocs from the $B$ and Natural groups. In addition, the mean nutritional composition of the biofloc in group $G$ showed a higher content of lipids and nitrogen-free extract.
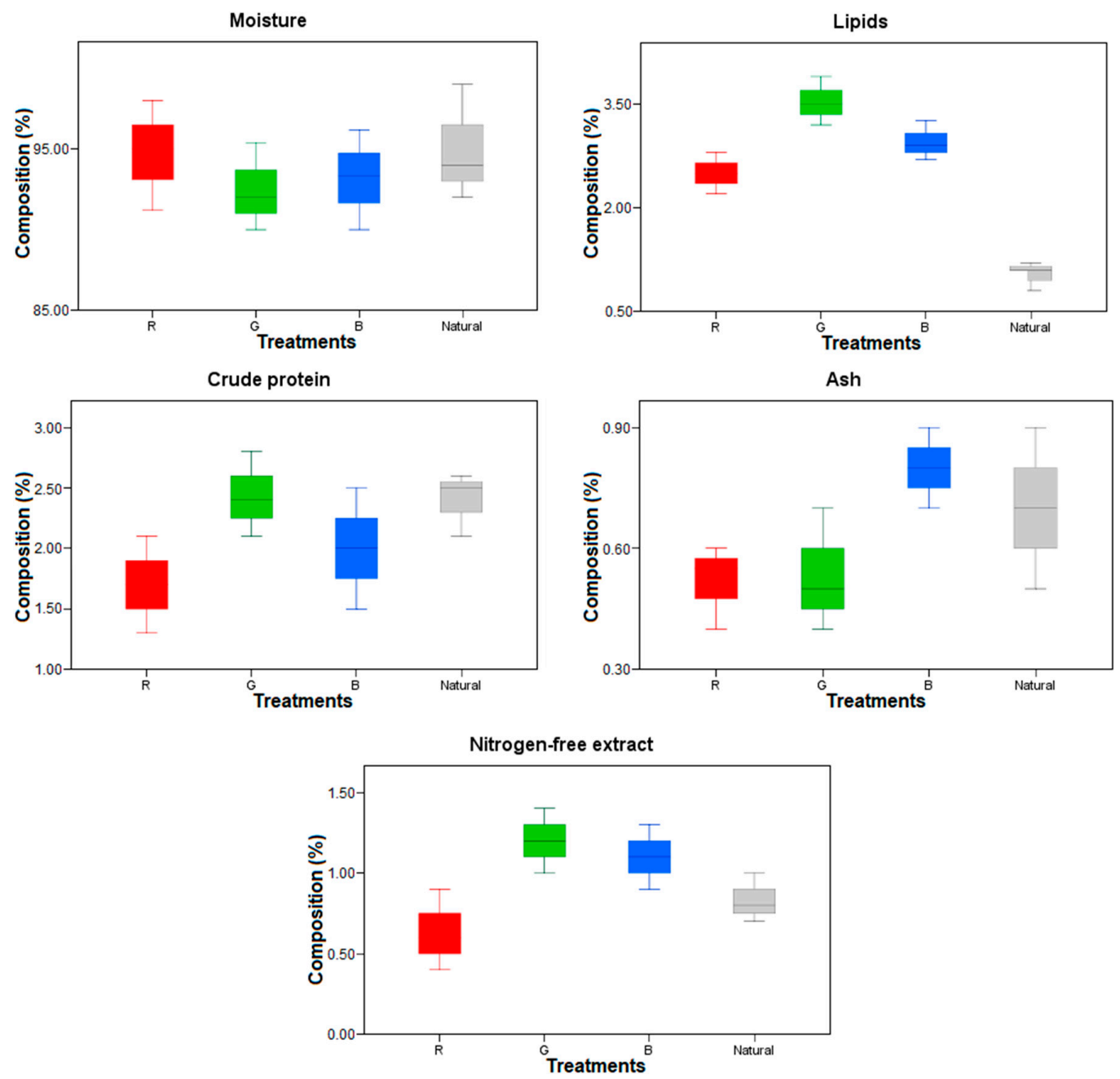

Figure 5. Box-and-whisker plots showing the nutritional composition of the biofloc (\%).

\section{Discussion}

To investigate the effect of colored light in the Nile tilapia fingerlings, the parameters that were not related to the light color were kept constant, but there were slight experimental variations in these parameters that are expected not to significantly change this condition of the research. The mean water temperature was maintained at less than $1{ }^{\circ} \mathrm{C}$ of variation, and all the tank water temperatures were in accordance with the optimum range for the growth of the Nile tilapia fingerlings $\left(26-30{ }^{\circ} \mathrm{C}\right)$, as indicated in [35]. The mean water temperature in the four treatments was $28.50{ }^{\circ} \mathrm{C}$, which is very close to the ideal temperature of $28^{\circ} \mathrm{C}$, as reported in [36]. The dissolved oxygen value did not have a very significant variation between all the groups and it was above the level that was acceptable for Nile tilapia ( $4-5 \mathrm{mg} / \mathrm{L})$, in accordance with [37]. The $\mathrm{pH}$ fluctuated between 7 and 8 during the experimental stage, which is the most appropriate range in tilapia aquaculture to obtain the optimum growth and survival rate, as recommended by [38]. The $\mathrm{pH}$ value was not different between the $\mathrm{R}, \mathrm{G}$, and $\mathrm{B}$ groups, which could be because of a greater total amount of bacterial activity that is influenced by the use of artificial light compared to the Natural group. Using a $\mathrm{C} / \mathrm{N}$ ratio of 20 , the TAN concentration has a 
similar behavior value to $\mathrm{pH}$ and it was maintained at levels that are suitable for Nile tilapia, according to [39]. The $\mathrm{NH}_{3}-\mathrm{N}$ values did not exceed the levels that were considered lethal for Nile tilapia during the experiment, and this value remained below the recommended limit of $0.1 \mathrm{mg} / \mathrm{L} \mathrm{[40].}$

Light color was the only intentionally different parameter among all treatments. Therefore, each treatment was only influenced by a certain color or wavelength of the light. There are not many studies reported of the influence of colored light on the growth of Nile tilapia and fish of different species in general [18], and as far as we know, this is the first study on the fingerling stage of development of tilapia. Even more, all previous studies on light effect use other experimental conditions, which include significant differences in: The lack of biofloc, the type or duration of photoperiod, the temperature, the light intensity, peak wavelengths, light spectrum shapes, etc.

In this research, we studied the effect of colored light in Nile tilapia fingerlings and bioflocs, the $\mathrm{R}$ light treatment was the aquaculture system that showed superior performance in many aspects. All the groups received the amount of food according to the biomass that was present in each tank.

It is possible to ensure that the $\mathrm{R}$ treatment presented the best growth performance because it obtained the best values of total biomass gained, SGR, and DWG. Additionally, there was a great demand for feed intake; when food was provided it was consumed immediately, which was confirmed because the R treatment had the best FCR of 0.8. This is consistent with [41], where feeding conduct was analyzed, but in juvenile Nile tilapia under other experimental conditions, showing (in terms of time (seconds), and chemical cues) that feeding motivation was higher in their red light environment. As well, a similar behavior was found in adult rainbow trout [42], where the growth of fish was increased at red illumination under other experimental conditions, showing low cortisol levels in their blood (less stressful environments).

Nevertheless, the G light environment showed the second-best weight gain, but also had the lowest survival. It is possible to rule out that the low survival was caused by a peak of ammonia and TAN, because during the period in which these fish deaths occurred, measurements of ammonia and TAN were in the optimal range for the life of tilapia. A similar low survival phenomenon using green light was also observed and reported in [43], but in small fish groups (four fish per tank) of adult tilapia under fluorescent lights and other experimental conditions. One possible reason to this phenomenon could be that an aggressive behavior of the fish was observed in a green light environment. Other related study determined (by blood test) the basal plasma cortisol levels (stress response) in adult Nile tilapia, and it was found that cortisol levels increased with green light [44]. This could be a cause of fish mortality because the green light may create stressful environment and increase cortisol levels. A high level of cortisol also affects the nutritional composition of tilapia, causing high moisture levels and low protein levels [45], which agree with our results. The low level of protein can be attributed to an intensive use of muscle protein to get higher energy than that obtained from food, which could be caused by the stress due to green light [46]. Green light may be an important factor of mortality, but research with replicate tanks should be carried out to see all possible mortality factors.

Aly et al. [45] reported that hybrid red tilapia in saline water had a lower growth performance under blue light and other experimental conditions. These results were attributed to a reduced vision of the fish under green light, which reduced feeding (also see [47]). In addition, they reported that hybrid red tilapia that were illuminated under red light had the best growth performance [45]. These observations are in agreement with our results, where the Nile tilapia fingerlings in freshwater under blue light had the lowest growth performance, and those under red light had the best growth performance. In addition, in [43], yellow light was shown to have the best growth performance, which also agrees with our results, because the yellow light has a long wavelength that is close to the wavelength of the red light.

In our research, the effect of colored light on the nutritional composition of Nile tilapia fingerlings, and on the biofloc composition as a food source for tilapia was also measured, and this has not been reported before. The effect of light on body composition of tilapia showed that the $\mathrm{R}$ group had the highest lipid content and also the lowest moisture level (this indicates that moisture and lipid content 
are inversely related, which is in accordance with [48]). However, under blue light, the fish had the highest percentage of protein and moisture and the lowest level of lipids, while under green light, the fish maintained a low content of lipids and proteins. Under natural light, the fish obtained a high crude protein content and the highest content of ash.

The effect of light color on bioflocs showed that the $G$ group had the highest lipid content. In addition, the bioflocs in the $G$ and Natural groups had the highest protein level. For the ash content, $\mathrm{B}$ and Natural groups had the highest percentage. In addition, although the biofloc of $\mathrm{B}$ group had a high level of lipids, the fish nutritional composition under B light had a low level of lipids. This opposite relationship could be explained by the stress reduction under blue light [44], and also a stress reduction under the lipid-rich diet [49]. Such a possible stress reduction, would reduce the formation of lipid deposits in fish, indicating that such good health condition of tilapia under B light could be because the lack of stress.

The results discussed above may have an important application in tilapia aquaculture with biofloc systems because they improve our understanding of the significant effect that light color has on the growth of fish and their nutritional composition of both the fish body and the bioflocs.

\section{Conclusions}

We investigated the influence of RGB colored light on the growth and nutritional composition in tilapia in biofloc systems. We also measured the light effect on the biofloc nutritional composition. The results showed that the peak wavelength or color of light had a significant effect on growth performance and nutritional composition of Nile tilapia, which can be used to improve the sustainability and efficiency of tilapia production based on the needs of the consumer. Fish under blue light had the lowest growth performance, but blue light significantly improved the protein levels, had a low lipid level, and obtained the most homogeneous growth among the treatments. The effect of the red light on fish growth was significant. Tilapia under red light showed the best weight gain, body length, and survival rate, and also showed the highest lipid content. The fish also had a lower ash content under colored light compared to natural light. In addition, colored light influenced the lipid, protein, and ash content in bioflocs.

These results provide support for further studies in aquaculture to improve efficient, sustainable, and intensive fish production. For example, our results suggest that growth rates, feed utilization efficiency, survival, and nutritional body composition may be controlled using colored light, which can significantly modify the nutritional quality provided by Nile tilapia and bioflocs. In addition, future research may include the effect of different intensity levels, photoperiods, and light spectra. For example a broad light spectrum with a designed special shape [50], resulting from the combination of LEDs of different colors and intensities, to obtain the best effects of each light wavelength and maximize the nutritional quality of tilapia and bioflocs. This can be adjusted based on the needs of the consumer and, in the future, the scarcity of food resources.

Author Contributions: Conceptualization, D.L.-B., C.O.-O. and I.M.; Methodology, D.L.-B. and C.G.-M.; Validation, C.O.-O. and I.M.; Formal analysis, D.L.-B., and C.G.-M.; Investigation, D.L.-B. and C.G.-M.; Resources, C.O.-O., D.G.-M. and M.d.J.M.P.; Data curation, D.L.-B. and M.d.J.M.P.; Writing-original draft preparation, D.L.-B.; Writing-review and editing, I.M., and D.L.-B.; Visualization, C.G.-M. and D.G.-M.; Supervision, C.O.-O. and I.M.; Project administration, I.M., C.O.-O. and M.d.J.M.P. All authors have read and agreed to the published version of the manuscript.

Funding: This research received no external funding.

Acknowledgments: This research was supported by CONACYT (Mexican Council for Science and Technology) through financing scholarship granted to Daniela Lopez-Betancur.

Conflicts of Interest: The authors declare no conflict of interest. 


\section{References}

1. Belton, B.; Bush, S.R.; Little, D.C. Not just for the wealthy: Rethinking farmed fish consumption in the Global South. Glob. Food Secur. 2017, 16, 85-92. [CrossRef]

2. FAO. Contributing to food security and nutrition for all. In The State of World Fisheries and Aquaculture, 2016; FAO: Rome, Italy, 2016; p. 172.

3. Pauly, D.; Zeller, D. Comments on FAOs state of world fisheries and aquaculture (SOFIA 2016). Mar. Policy 2017, 77, 176-181. [CrossRef]

4. WWAP. The United Nations World Water Development Report 2015: Water for a Sustainable World; UNESCO: Paris, France, 2015.

5. Arias-Moscoso, J.L.; Espinoza-Barrón, L.G.; Miranda-Baeza, A.; Rivas-Vega, M.E.; Nieves-Soto, M. Effect of commercial probiotics addition in a biofloc shrimp farm during the nursery phase in zero water exchange. Aquac. Rep. 2018, 11, 47-52. [CrossRef]

6. Avnimelech, Y. Feeding with microbial flocs by tilapia in minimal discharge bio-flocs technology ponds. Aquaculture 2007, 264, 140-147. [CrossRef]

7. Avnimelech, Y.; Verdegem, M.; Kurup, M.; Keshavanath, P. Sustainable land-based aquaculture: Rational utilization of water, land and feed resources. Mediterr. Aquac. J. 2008, 1, 45-55. [CrossRef]

8. Azim, M.E.; Little, D.C. The biofloc technology (BFT) in indoor tanks: Water quality, biofloc composition, and growth and welfare of Nile tilapia (Oreochromis niloticus). Aquaculture 2008, 283, 29-35. [CrossRef]

9. Emerenciano, M.; Ballester, E.L.; Cavalli, R.O.; Wasielesky, W. Biofloc technology application as a food source in a limited water exchange nursery system for pink shrimp Farfantepenaeus brasiliensis (Latreille, 1817). Aquac. Res. 2012, 43, 447-457. [CrossRef]

10. Green, B.W.; Rawles, S.D.; Webster, C.D.; McEntire, M.E. Effect of Stocking Rate on Growing Juvenile Sunshine Bass, Morone chrysops x M. saxatilis, in an Outdoor Biofloc Production System. J. World Aquac. Soc. 2018, 49, 827-836. [CrossRef]

11. Avnimelech, Y. Biofloc technology. In A Practical Guide Book; The World Aquaculture Society: Baton Rouge, LA, USA, 2009; p. 182.

12. Crab, R.; Defoirdt, T.; Bossier, P.; Verstraete, W. Biofloc technology in aquaculture: Beneficial effects and future challenges. Aquaculture 2012, 356, 351-356. [CrossRef]

13. Boeuf, G.; Le Bail, P.Y. Does light have an influence on fish growth? Aquaculture 1999, 177, 129-152. [CrossRef]

14. Ridha, M.; Cruz, E. Effect of light intensity and photoperiod on Nile tilapia Oreochromis niloticus L. seed production. Aquac. Res. 2000, 31, 609-617. [CrossRef]

15. Moyle, P.B.; Cech, J.J. Fishes: An Introduction to Ichthyology; Pearson Prentice Hall: Upper Saddle River, NJ, USA, 2004.

16. Heydarnejad, M.S.; Parto, M.; Pilevarian, A.A. Influence of light colours on growth and stress response of rainbow trout (Oncorhynchus mykiss) under laboratory conditions. J. Anim. Physiol. Anim. Nutr. 2013, 97, 67-71. [CrossRef] [PubMed]

17. Karakatsouli, N.; Papoutsoglou, E.S.; Sotiropoulos, N.; Mourtikas, D.; Stigen-Martinsen, T.; Papoutsoglou, S.E. Effects of light spectrum, rearing density and light intensity on growth performance of scaled and mirror common carp Cyprinus carpio reared under recirculating system conditions. Aquac. Eng. 2010, 42, 121-127. [CrossRef]

18. Ruchin, A.B. Environmental colour impact on the life of lower aquatic vertebrates: Development, growth, physiological and biochemical processes. Rev. Aquac. 2018, 1-18. [CrossRef]

19. Ruchin, A.B. Influence of Colored Light on Growth rate of Juveniles of Fish. Fish Physiol. Biochem. 2004, 30, 175-178. [CrossRef]

20. Karakatsouli, N.; Papoutsoglou, S.E.; Pizzonia, G.; Tsatsos, G.; Tsopelakos, A.; Chadio, S.; Kalogiannis, D.; Dalla, C.; Polissidis, A.; Papadopoulou-Daifoti, Z. Effects of light spectrum on growth and physiological status of gilthead seabream Sparus aurata and rainbow trout Oncorhynchus mykiss reared under recirculating system conditions. Aquac. Eng. 2007, 36, 302-309. [CrossRef]

21. Bayarri, M.; Madrid, J.; Sánchez-Vázquez, F. Influence of light intensity, spectrum and orientation on sea bass plasma and ocular melatonin. J. Opineal Res. 2002, 32, 34-40. [CrossRef] 
22. Hoang, T.; Barchiesis, M.; Lee, S.Y.; Keenan, C.P.; Marsden, G.E. Influences of light intensity and photoperiod on moulting and growth of Penaeus merguiensis cultured under laboratory conditions. Aquaculture 2003, 216, 343-354. [CrossRef]

23. Neal, R.S.; Coyle, S.D.; Tidwell, J.H.; Boudreau, B.M. Evaluation of stocking density and light level on the growth and survival of the Pacific white shrimp, Litopenaeus vannamei, reared in zero-exchange systems. J. World Aquac. Soc. 2010, 41, 533-544. [CrossRef]

24. Njiru, M.; Okeyo-Owuor, J.; Muchiri, M.; Cowx, I. Shifts in the food of Nile tilapia, Oreochromis niloticus (L.) in Lake Victoria, Kenya. Afr. J. Ecol. 2004, 42, 163-170. [CrossRef]

25. Moreno, I.; Contreras, U. Color distribution from multicolor LED arrays. Opt. Express 2007, 15, 3607-3618. [CrossRef] [PubMed]

26. Moreno, I.; Sun, C.C. Modeling the radiation pattern of LEDs. Opt. Express 2008, 16, 1808-1819. [CrossRef] [PubMed]

27. De Schryver, P.; Crab, R.; Defoirdt, T.; Boon, N.; Verstraete, W. The basics of bio-flocs technology: The added value for aquaculture. Aquaculture 2008, 277, 125-137. [CrossRef]

28. Crab, R.; Kochva, M.; Verstraete, W.; Avnimelech, Y. Bio-flocs technology application in over-wintering of tilapia. Aquac. Eng. 2009, 40, 105-112. [CrossRef]

29. Poli, M.A.; Legarda, E.C.; de Lorenzo, M.A.; Martins, M.A.; do Nascimento Vieira, F. Pacific white shrimp and Nile tilapia integrated in a biofloc system under different fish-stocking densities. Aquaculture 2019, 498, 83-89. [CrossRef]

30. Boyd, C.E.; Tucker, C.S. Pond Aquaculture Water Quality Management; Springer Science and Business Media: Medford, MA, USA, 2012; ISBN 978-1-4615-5407-3.

31. Mansour, A.T.; Esteban, M.Á. Effects of carbon sources and plant protein levels in a biofloc system on growth performance, and the immune and antioxidant status of Nile tilapia (Oreochromis niloticus). Fish Shellfish. Immunol. 2017, 64, 202-209. [CrossRef]

32. Nhi, N.H.Y.; Da, C.T.; Lundh, T.; Lan, T.T.; Kiessling, A. Comparative evaluation of Brewer's yeast as a replacement for fishmeal in diets for tilapia (Oreochromis niloticus), reared in clear water or biofloc environments. Aquaculture 2018, 495, 654-660. [CrossRef]

33. AOAC. Official Methods of Analysis of AOAC International, 18th ed.; AOAC International: Gaithersburg, MD, USA, 2005.

34. NMX Water Analysis-Measurement of Extractables Fats and Oils in Natural Waters, Wastewaters and Treated Wastewaters; Diario Oficial de la Federacion de la Secretaria de Economia del Gobierno de Mexico: Ciudad de Mexico, CDMX, Mexico, 2013.

35. Azaza, M.; Dhraief, M.; Kraiem, M. Effects of water temperature on growth and sex ratio of juvenile Nile tilapia Oreochromis niloticus (Linnaeus) reared in geothermal waters in southern Tunisia. J. Therm. Biol. 2008, 33, 98-105. [CrossRef]

36. El-Sayed, A.F.M.; Kawanna, M. Optimum water temperature boosts the growth performance of Nile tilapia (Oreochromis niloticus) fry reared in a recycling system. Aquac. Res. 2008, 39, 670-672. [CrossRef]

37. Evans, J.J.; Shoemaker, C.A.; Klesius, P.H. Effects of sublethal dissolved oxygen stress on blood glucose and susceptibility to Streptococcus agalactiae in Nile tilapia Oreochromis niloticus. J. Aquat. Anim. Health 2003, 15, 202-208. [CrossRef]

38. El-Sherif, M.S.; El-Feky, A.M.I. Performance of Nile tilapia (Oreochromis niloticus) fingerlings. I. Effect of $\mathrm{pH}$. Int. J. Agric. Biol. 2009, 11, 297-300.

39. Zeitoun, M.M.; EL-Azrak, K.E.D.M.; Zaki, M.A.; Nemat-Allah, B.R.; Mehana, E.S.E. Effects of ammonia toxicity on growth performance, cortisol, glucose and hematological response of Nile Tilapia (Oreochromis niloticus). Aceh. J. Anim. Sci. 2016, 1, 21-28. [CrossRef]

40. El-Shafai, S.A.; El-Gohary, F.A.; Nasr, F.A.; van der Steen, N.P.; Gijzen, H.J. Chronic ammonia toxicity to duckweed-fed tilapia (Oreochromis niloticus). Aquaculture 2004, 232, 117-127. [CrossRef]

41. Volpato, G.L.; Bovi, T.S.; de Freitas, R.H.; da Silva, D.F.; Delicio, H.C.; Giaquinto, P.C.; Barreto, R.E. Red light stimulates feeding motivation in fish but does not improve growth. PLoS ONE 2013, 8, e59134. [CrossRef]

42. Karakatsouli, N.; Papoutsoglou, S.E.; Panopoulos, G.; Papoutsoglou, E.S.; Chadio, S.; Kalogiannis, D. Effects of light spectrum on growth and stress response of rainbow trout Oncorhynchus mykiss reared under recirculating system conditions. Aquac. Eng. 2008, 38, 36-42. [CrossRef] 
43. Luchiari, A.; Freire, F. Effects of environmental colour on growth of Nile tilapia, Oreochromis niloticus (Linnaeus, 1758), maintained individually or in groups. J. Appl. Ichthyol. 2009, 25, 162-167. [CrossRef]

44. Volpato, G.L.; Barreto, R. Environmental blue light prevents stress in the fish Nile tilapia. Braz. J. Med. Biol. Res. 2001, 34, 1041-1045. [CrossRef]

45. Aly, H.; Abdel-Rahim, M.; Lotfy, A.; Abdelaty, B. Impact of Different Colors of Artificial Light on Pigmentation and Growth Performance of Hybrid Red Tilapia (Oreochromis mosambicus x O. hornorum) Reared in Saline Well Water. J. Mar. Sci. Res. Dev. 2017, 7, 229. [CrossRef]

46. Sabri, D.M.; Elnwishy, N.; Nwonwu, F. Effect of environmental color on the behavioral and physiological response of Nile tilapia, Oreochromis niloticus. Glob. J. Front. Res. 2012, 12, 11-20.

47. Douglas, R.H.; Hawryshyn, C.W. Behavioural studies of fish vision: An analysis of visual capabilities. In The Visual System of Fish; Douglas, R., Djamgoz, M., Eds.; Springer: Dordrecht, The Netherlands, 1990; pp. 373-418. ISBN 978-94-009-0411-8.

48. Younis, E.S.M.; Al-Quffail, A.S.; Al-Asgah, N.A.; Abdel-Warith, A.W.A.; Al-Hafedh, Y.S. Effect of dietary fish meal replacement by red algae, Gracilaria arcuata, on growth performance and body composition of Nile tilapia Oreochromis niloticus. Saudi J. Biol. Sci. 2018, 25, 198-203. [CrossRef]

49. He, A.Y.; Ning, L.J.; Chen, L.Q.; Chen, Y.L.; Xing, Q.; Li, J.M.; Qiao, F.; Li, D.L.; Zhang, M.L.; Du, Z.Y. Systemic adaptation of lipid metabolism in response to low- and high-fat diet in Nile tilapia (Oreochromis niloticus). Physiol. Rep. 2015, 3, e12485. [CrossRef] [PubMed]

50. Moreno, I.; Ramos-Romero, I.R. Light spectrum for maximum luminous efficacy of radiation and high color quality. In Current Developments in Lens Design and Optical Engineering XIX; International Society for Optics and Photonics: Bellingham, WA, USA, 2018; Volume 10745.

(C) 2020 by the authors. Licensee MDPI, Basel, Switzerland. This article is an open access article distributed under the terms and conditions of the Creative Commons Attribution (CC BY) license (http://creativecommons.org/licenses/by/4.0/). 